\title{
Design and development of values education index and perceptual mapping in Indian perspective
}

\author{
${ }^{1}$ Ram Komal Prasad, ${ }^{2}$ Manish Kumar Srivastava \\ ${ }^{1}$ Associate Professor, Institute of Cooperative and Corporate Management, Research and Training, Lucknow \\ ${ }^{2}$ Doctoral scholar, Indian Institute of Technology, Delhi (Thesis submitted)
}

\begin{abstract}
The present research works explore the constructs contributing to the values of education in the Indian educational framework and make an effort to understand its perception among the stakeholders. We have made a scientific effort to explore various dimensions of value education constructs from available literature and shaped those constructs on the perceptual mapping framework that have created its positions on the graphic dimension of the frame. It explains how the value education contributes to shaping the mindset and personality amongst the students. We have developed a value education index on the identified constructs that shows the relative weights on each identified construct. The constructs identified as family cohesion, parent conflicts, parents expatiation, teachers' role, school administration, mass media and internet, social orientation, community structure, religious education, and public institution.
\end{abstract}

Key words: Value education, perceptual map, value education index, higher education

DOI: $10.7176 / \mathrm{JEP} / 11-33-20$

Publication date: November $30^{\text {th }} 2020$

\subsection{Introduction}

Value education contributes to shaping the positive thought process among the students in their adolescent age it carries out lifelong. The mental growths of the students grasp both the positive and negative aspects of the thought along with the growing age. The thought once acquired in personality the perception develops as per thought process and the individual carries lifelong irrespective of social norms, culture or symbols. The value education sideline most of the ill-thought and inherit socially accepted norms and the stakeholder's practices boldly irrespective of other greed, wrong and unsocial behaviors thus perform productive column at the workplace, in family and finally in the society. Value education shares all-around development mental, moral, spiritual, and behavioral. Since formal education is an instrument for social, economic, and cultural adaptability hence there is an intense need of instilling value education parallel to formal education. In the same way, professional education instills skills and techniques; there seems a requirement of value education frame which can be an unified model. Formal education and professional education undoubtedly contributes to earning a livelihood but value education directs how fairly earn the livelihood and develop thought process how to contribute to the society and the nation at large. Society is also suffering from a number of ill-treatment to adolescents, girl child, old aged persons, least concerns to family members, corruption in personal and professional life, accumulation of wealth unfairly, fraudulent activities, criminal mindset, molestation to women, etc. and hence the need of instilling the values and ethics in the brains of the college-going students felt by the responsible citizens and the researchers in the domain of education. The value education undoubtedly as we presume, shall contribute in establishing our aged-old tradition viz. the state of unity, civic efficiency, aesthetic sensibility, peace and harmony, and building the impressive character.

The hurdle to achieving the goal of education is the degradation of values in the current social scenario. The social values and ethics are degrading, human behavior changing as per the situation, preferences of individuals acquire certain definiteness, intensity, and stability, and these become the criteria for judgment, choice, action, and ground for decision making in day to day life. Personal interest aggregates over public interest, which had been observed through corruptions the collapse of national economies institutions and corporate. Highly educated/ professionally educated individuals find out loopholes in the set norms and do undesired activities just to have the satisfaction of having the wealth and the power of wealth. It is seen in the context of the absence of such human values as honesty, integrity, and a sense of justice that strike shattering blows, even at hardcore professional business organizations.

The inculcation of values (human and ethical) in school going children are more effective and long-lasting as compare to that university going students and adults. These individuals show transparency in their personal and professional dealings if they develop and practice values at the initial stage. Hence value-based education for 
children is essential for growth and prosperity in every sphere-whether it is in the economy, politics, or social service. Education provides individuals with the ability to live creatively, peacefully, responsibly, within a community, and to become the instruments of change for a better society (UNESCO, 2014). Despite considerable progress made since India gained independence, Indian society still has its share of scams, conflicts, corruption, and violence. This, it has been argued, is mostly because of distortion in the values system of the youth (Lee, 1994; Jain, 2012).

\subsection{Concepts and Definition of Values}

The International Encyclopedia of Social Sciences (Sills, 1968) defines values as 'a set of principles whereby conduct is directed and regulated as a guide for individual or social groups.' Values alter human behavior on a regular basis; they are based on needs and preferences. When preferences become more definite, intense, and stable, these become the criteria for judgment, choice, and action, i.e. the grounds for decision making (Gulati \& Pant, 2017). According to Swami Vivekananda (1893), 'values bring harmony to society, uphold justice and buildup cordial relationship, a society without values will sooner or later collapse, leading to chaos and destruction.

Children and youths must be skilled to put into practice values of peace and harmony, both within themselves and with others (UNESCO, 1998); they are the representatives of the future. According to a projection of population, India will have, by 2020, one of the youngest populations worldwide (Shivakumar, 2013) and this huge human resource will shape both India and the rest of the world. Children are educated by the entirety of the environment in which they grow up, an environment that is determined by teachers, parents and the surrounding community (Strong-Wilson \& Ellis, 2007). As education is the main driving force of social change and individual reformation, it is impossible to bring about a fundamental change in a society unless the individuals themselves are changed.

\subsection{Values Education in Schools}

It is extensively acknowledged that education is always with values (Carbone, 1991; Hatton, 1998; Halstead, 1996; Hooper et al 2003; Lovat \& Schofield, 2004b; Veugelers, 2000; Veugelers \& Vedder, 2003). Aspin (2005) points to the ubiquity of values as they permeate all aspects of education. Children and youth need to be trained to exercise the normally held values of agreement and amity with self and others (UNESCO, 1998). Children are emissaries of the upcoming time. As per the population projection, India will have one of the youngest populations in the world by 2020 (Shivakumar, 2013). This vast human resource must shape the nation and the world. The child is educated by the complete atmosphere in which it grows, and that environment is created by the parents, teachers, and society around (Strong-Wilson \& Ellis, 2007). Education is the key activity for community transformation. It is not possible to bring basic changes in society unless the individual's attitude is changed.

From the perspective of individual children, their homes are the first and primary learning environments and educators in values, but school obtains an increasing role with age. Moral education permeates the school curriculum, the rules of the school, and teachers' individual principles (Tirri, 1998). Mitra (2018) reiterated that right from the primary school stage, intentional, planned, and continuous efforts to be made to instill essential human values in the students.

\subsection{Review of relevant literature}

We have reviewed most of the available literature to understand the existing values education systems and various models that have been published time to time related to various dimensions of values education and its importance to the students at large. These efforts allowed the researchers to ensure our research questions which have not been previously answered, identify gaps in the literature, and note possible research methods for our present studies. These literature reviews have facilitated us to identified previous researches motives, objectives, current research problems that have been done on social capital, value, and ethics in society, development of ethical philosophy. Adequate research has been done in the value education but the majority is regarding policy studies, structural studies at schools and studies on moral education, human social capital, and intellectual capital.

\subsection{Values in modern education}

Values are measured as norms for judging the character, psychology and worth of individuals. These are norms by which we evaluate things, people, objects, ideas, actions, and circumstances valuable (Shaver and Strong, 
1976). Values bring harmony to society; sustain justice, and buildup cordial relationship. A society without values sooner or later would collapse, leading to chaos and destruction in social system.

We have summarized the views of authors and their contribution to values education systematically with author names, published year, their value description etc.

Authors

Table 1: Descriptions of values from literature

\begin{tabular}{l|l|}
\hline Gibbs, 1965 & Social belief, ideal or norm \\
\hline Sikula,1971 & $\begin{array}{l}\text { Represent wants, preferences, likes and/ or dislikes for particular things, } \\
\text { conditions and situations. }\end{array}$ \\
\hline Rokeach, 1973 & $\begin{array}{l}\text { An enduring belief, specific mode of conduct or end state existence along a } \\
\text { continuum of relative importance. }\end{array}$ \\
\hline $\begin{array}{l}\text { Venkataiah, N. } \\
\text { (Ed.). (1998). }\end{array}$ & Set of principles or standards of behavior. \\
\hline Hill, 2005 & $\begin{array}{l}\text { Beliefs held by individuals to which they attach special priority or worth, and } \\
\text { by which they tend to order their lives. A value is, therefore, more than a } \\
\text { belief; but it is also more than a feeling. }\end{array}$ \\
\hline $\begin{array}{l}\text { Prahalad \& } \\
\text { Hammond, 2002 }\end{array}$ & $\begin{array}{l}\text { Socially defined desires and goals that are internalized through the process of } \\
\text { conditioning learning and socialization. }\end{array}$ \\
\hline Gharote,2002 & A belief about what is desirable or undesirable. \\
\hline Huitt,2004 & $\begin{array}{l}\text { The norms and standards of a given society in a certain time scale and } \\
\text { influence its total structure through which men grow. }\end{array}$ \\
\hline Wilson et al., 2010 & $\begin{array}{l}\text { Freely chosen, verbally constructed consequences of ongoing, dynamic, } \\
\text { evolving patterns of activity, which establish predominant re-inforcers for } \\
\text { that activity that are intrinsic in engagement in the valued behavioral pattern } \\
\text { itself. }\end{array}$ \\
\hline Sharma,2015 & Qualities that a person has learned to believe are important or worthwhile. \\
\hline 2016 & $\begin{array}{l}\text { It plays a very important role in the lives of individuals, groups and societies } \\
\text { and becomes a subject of education. }\end{array}$ \\
\cline { 2 - 2 } &
\end{tabular}

From the table above, a broad description of the work concept of values have been described. Human emotions like thought, idea, feeling, sentiment or emotion could promote to integrate growth of the personality of the individual that could be value dimensions with positivity. Values also contribute to the welfare of the larger social units such as family, the community, the nation, and the world of which the individual is a member.

\subsection{Values Education}

Value-education is a multi-facet endeavor and is a time-span during which youth are helped by grownups or elderly people in schools, family, home, society, and religious and other organizations, to make clear those own underlying attitudes, to measure the effectiveness of these values for their own comfort and to reflect on and gain other values which are more effective for sustainable gain (Gulati \& Pant, 2017). 
Table: 2 Descriptions of value education from literature

\section{Authors \\ Description of values education}

\begin{tabular}{|c|c|}
\hline Good \& Good, 1959 & $\begin{array}{l}\text { Values education is the sum of all the techniques, by which a person } \\
\text { Inculcates capabilities, attitudes and other forms of behavior that includes } \\
\text { positive values in the surrounding society. }\end{array}$ \\
\hline Raths, et al.,1966 & $\begin{array}{l}\text { It is mainly related with teaching students to discover and develop their } \\
\text { own values. }\end{array}$ \\
\hline $\begin{array}{l}\text { Simon\& Howe, } \\
1972\end{array}$ & It is student-oriented teaching method to help them understand their feelings \\
\hline Seshadri et al 1992 & $\begin{array}{l}\text { It is a process of encouraging learning. It enables students to contemplate, } \\
\text { reason, replicate, question, feel, care, the experience will, } \\
\text { and act. }\end{array}$ \\
\hline Seshadri et al 1992 & $\begin{array}{l}\text { Values education involves working on the complete personality of the } \\
\text { person maintaining all aspects of character development, the rational, } \\
\text { societal and sensitivity, and determination. }\end{array}$ \\
\hline Aitken, 2006 & $\begin{array}{l}\text { Value Education provides motivation and guidance to our youngsters. It } \\
\text { builds character which is beneficial for growth of both the individual and the } \\
\text { society in general }\end{array}$ \\
\hline $\begin{array}{l}\text { Thornberg, R., } \\
2013\end{array}$ & $\begin{array}{l}\text { All activities in schools in which students learn or develop values and } \\
\text { morality are often referred to as value education }\end{array}$ \\
\hline Katilmis, A., 2017 & $\begin{array}{l}\text { values education helps in raising a generation able to contribute to creating a } \\
\text { livable world. }\end{array}$ \\
\hline Genc, M. F., 2018 & $\begin{array}{l}\text { Values education is process in which the child is advised what he or she } \\
\text { should or should not do and is taught what is right and what is wrong }\end{array}$ \\
\hline
\end{tabular}

Values education is at the center of curricula and the educational process; all educational systems must include values in the learning process, were it excluded, the system's potential effects on students' academic learning and happiness would be lessened (Lovat \& Clement, 2008). Value education is the combination of all the processes through which individuals develop attitudes, abilities, and other types of behavior related to the positive values held in the society in which they live (Good \& Good, 1959). Values education's aim is to the overall development of body, mind, and spirit (Gandhi \& Menon, 1956).

One of the highly cited research papers in this area is authored by Lovat \& Clement (2008), titled "Quality teaching and values education: Coalescing for effective learning". In this empirical study, the authors has tried to determine the connection between awareness of the potential of quality teaching and student accomplishment. This research extends the comprehension of the conception of 'teacher' beyond information-based learning to that of bringing on in-depth learning at a rational level, which requires the application of communication and self-reflective abilities. Quality teaching helps educators to perform explicit teaching in values education, and in turn, it helps to achieve the educational objectives implied in quality teaching. It can be concluded that values education is the affective and relational aspect of teaching that gradually gives it, its strengths and positive impact. The authors have used the data from the Australian Government's "Good Practice Schools" project. 
Lovat, et al. (2010), explained in a paper entitled "Values education as holistic development for all sectors: Researching for effective pedagogy" that values edification is no longer the sacred agenda of faith schools, but it has become the central idea to be incorporated inefficient pedagogy. It is a critical issue in education in any school setting. The analysis and the findings were drawn from public funded projects in Australia. The authors studied the relationship of values education with school effectiveness and school ambiance. They concluded that highquality values education contributes to holistic learning, including the academic progress of students.

Thornberg, R. (2008), authored a book "The lack of professional knowledge in values education" which is qualitative research, tries to examine teachers' perceptions of their practice of values education and to explore their degree of professionalism. Thirteen (13) teachers have been interviewed and the data have been analyzed technically. The expressed their views, values education is (a) mostly immediate and ad hoc, (b) entrenched in everyday school life with a focus on the typical behavior of students in school, and (c) partially or fully unconsciously performed. Value education was absent and only professional knowledge in the field of values eduation among these teachers. Developing democratic skills by students from values education depends upon the students' abilities to participate in rule-making. There is a need of confident teachers with professional skill in providing values education (Thornberg, R., 2008).

\subsection{Factors related with values education}

Through intensive and careful investigation we have outlined constructs related with values education dominant in literature are shown in the following table.

\begin{tabular}{|c|c|c|c|}
\hline S.No. & Factors & Authors & Year \\
\hline \multirow[t]{2}{*}{1} & \multirow[t]{2}{*}{ Parents' education } & Devis \&Pamela & 2005 \\
\hline & & Abedini, S. & 2011 \\
\hline \multirow[t]{2}{*}{2} & \multirow[t]{2}{*}{ Parents' income } & Devis \&Pamela & 2005 \\
\hline & & Abedini, S. & 2011 \\
\hline 3 & Parents' job & Abedini, S. & 2011 \\
\hline 4 & Family size & Renolds et al. & 1996 \\
\hline 5 & Family values & Benner et al. & 2007 \\
\hline 6 & Parents' expectation & Benner et al & 2007 \\
\hline \multirow[t]{3}{*}{7} & \multirow[t]{3}{*}{ Parents' engagement } & Desforges et al. & 2003 \\
\hline & & Yaşaroğlu & 2016 \\
\hline & & Sylva et al. & 2004 \\
\hline 8 & Society and culture & Gjerde & 2004 \\
\hline 9 & Society norms & Furman et al. & 1996 \\
\hline \multirow[t]{2}{*}{10} & \multirow[t]{2}{*}{ Culture } & Furman et al. & 1996 \\
\hline & & Zajda & 2018 \\
\hline 11 & Social system & Furman et al. & 1996 \\
\hline \multirow[t]{2}{*}{12} & \multirow[t]{2}{*}{ local community } & Furman et al. & 1996 \\
\hline & & Zajda & 2018 \\
\hline 13 & Religious tolerance & Bawa \& Bhatnagar & 2016 \\
\hline
\end{tabular}




\begin{tabular}{|c|c|c|c|}
\hline 14 & Patriotism & Bawa \& Bhatnagar & 2016 \\
\hline \multirow[t]{2}{*}{15} & \multirow[t]{2}{*}{ Family } & Miller and Sears & 1986 \\
\hline & & Suriyachinnavar & 2016 \\
\hline 16 & Family violence & WJ Goode & 1971 \\
\hline 17 & Family values & Bernadette M. Delgado & 1998 \\
\hline 18 & Mass media & Taylor et al. & 2007 \\
\hline 19 & Curriculum & Zajda & 2018 \\
\hline 20 & Pedagogical support & Zajda & 2018 \\
\hline \multirow[t]{2}{*}{21} & \multirow[t]{2}{*}{ Religious education } & Tritter & 1992 \\
\hline & & Niculescu & 2013 \\
\hline 22 & Social work & Hayes \& Varley & 1965 \\
\hline \multirow[t]{6}{*}{23} & \multirow[t]{6}{*}{ Teacher } & Yaşaroğlu & 2016 \\
\hline & & Ranjani Balaji Iyer & 2013 \\
\hline & & Suriyachinnavar & 2016 \\
\hline & & Ray Calvin Owens Jr. & 1992 \\
\hline & & T. Lovat et al. & 2010 \\
\hline & & Tineh, Abdullah M & 2015 \\
\hline 24 & Parent-Teacher relationship & Yaşaroğlu & 2016 \\
\hline 25 & Technology & Tessa Jolls & 2008 \\
\hline 26 & Internet & Hameed & 2011 \\
\hline 27 & Home environment & Pamela E. Davis-Kean & 2005 \\
\hline \multirow[t]{2}{*}{28} & \multirow[t]{2}{*}{ Teacher student relationship } & Brady L. & 2011 \\
\hline & & T. Lovat et al. & 2010 \\
\hline \multirow[t]{4}{*}{29} & \multirow[t]{4}{*}{ Yoga education } & Bera, N. & 2017 \\
\hline & & C. Ferreira-Vorkapic & 2015 \\
\hline & & Jain,A. & 2014 \\
\hline & & Bera M. & 2012 \\
\hline \multirow[t]{2}{*}{30} & \multirow[t]{2}{*}{ Teacher Training } & Ranjani Balaji Iyer & 2013 \\
\hline & & Tineh, Abdullah M & 2015 \\
\hline 31 & Curriculum & Iscan \& Senemoglu & 2009 \\
\hline \multirow[t]{2}{*}{32} & \multirow[t]{2}{*}{ Peers } & Titus, Dale N. & 1994 \\
\hline & & Marvin W. Berkowitz & 2011 \\
\hline
\end{tabular}




\begin{tabular}{l|l|l|c|}
\hline $\mathbf{3 3}$ & Community service & Titus, Dale N. & 1994 \\
\cline { 3 - 4 } & & Marvin W. Berkowitz & 2011 \\
\hline $\mathbf{3 4}$ & Role Modeling & Marvin W. Berkowitz & 2011 \\
\hline $\mathbf{3 5}$ & Nurturance & Marvin W. Berkowitz & 2011 \\
\hline $\mathbf{3 6}$ & Teacher's perception & T. Lovat et al. & 2010 \\
\hline $\mathbf{3 7}$ & Sports & T. Lovat et al. & 2010 \\
\hline $\mathbf{3 8}$ & Classroom climate & T. Lovat et al. & 2010 \\
\hline $\mathbf{3 9}$ & Grand parents' influence & P Akhtar et al. & 2017 \\
\hline $\mathbf{4 0}$ & Student empowerment & T. Lovat et al. & 2010 \\
\hline $\mathbf{4 1}$ & Television & Gladkova, A. A. & 2013 \\
\hline $\mathbf{4 2}$ & Parental values & M Lotz & 2014 \\
\cline { 3 - 4 } & & &
\end{tabular}

\subsection{Objectives of the study}

a. To find our major constructs that contributes values education in India.

b. To understand the role of parents, teachers and principals in values education.

c. To provide a road map for implementing values education parameters in schools.

d. To design and develop a measurement scale for values education.

\subsection{Design and development of measurement scale for values-education}

On the basis of the review of the available relevant literature as elaborated, we have identified ten (10) constructs that have a genuine impact on the value education perception among the various stakeholders in the education system and 50 items were generated to take the relevant opinion as perceived by the respondents

Major dimensions affecting the perceived effectiveness of values education in schools were captured with the help of a literature review; focus group study. Initial screening of literature indicated the importance of family values, parents' engagement, parents' education, social system, mass media, curriculum, pedagogical support, teachers' role and perception, school vision, local community, religious tolerance, religions education, family size, society and culture, patriotism, internet, peers, community service, parent-teacher relationship, technology, home environment, and sports activities. In this study, attempts were made to formulate a measurement scale based on the above parameters and a conceptual framework, which evolved during the course of study. In order to develop a refined scale for the measurement of perceived effectiveness of values education in schools, a pilot study was conducted with the help of a focus group.

\subsection{Proposed model}

Based on our academic domain knowledge and discussion with other research scholar and professors, teachers imparting education at almost all levels viz. primary schools, junior schools, higher secondary schools even at degree and university level, we come across some basic commonalities, we proposed our tentatively proposed model in which ten (10) value education constructs have been taken that directs to the teachers who actually teach and instills knowledge rather than transfer the knowledge to the learners and the principal of the schools who is a seasoned earlier teacher having the skill of educational administration and understands the children psychology is competent to resolve children issues of quarrel or put aggressive arguments for trifling and innocent ideology, able to punish if it is beyond the teacher and create an ideal role model for the children at the schools assembly and common talk on various national occasions that generate the perceived effectiveness of value education among the children and learners. The principal also keep himself updated with school children activities, talk the parents time to time apart from the teachers' feedback give motivational and innovation ideology, compare with other known schools students engagement on various scientific and social projects, motivates for national service through 
various service corps, promote sharing habits, games, and academic and non-academic competitions, interschool meets, etc.

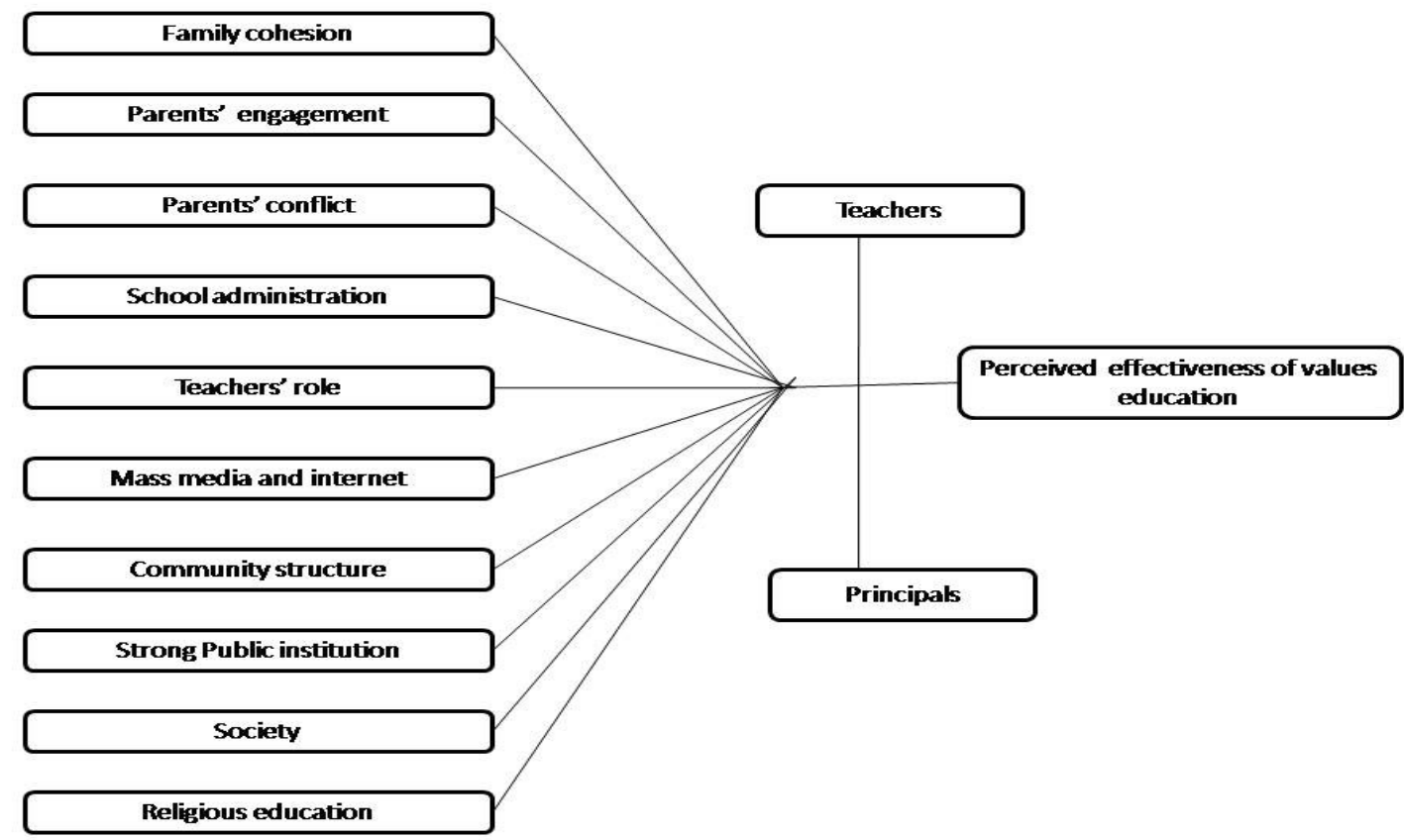

Figure: 1 Proposed values education framework

The present three-layer framework in which family, socials organization, socio-cultural activities, children's participation in family matters, community, mass media internet, etc. have a first focus on teachers and principals. Students assume them as their role models to a certain extent. Both the teachers and principals direct the effectiveness of value education as perceived by the students. We also assume that there may be certain mediating factors as well as extraneous factors having a crucial effect on the whole value chain of delivering value education to the students.

\subsection{Research methodology}

The methodology included identification of the boundary of the universe, selection of a sample of respondents, questionnaire design, and illustrations of statistical tools to analyze the data. For analysis of the data obtained, a scientific approach was used to derive meaningful conclusions.

\section{The population of the study}

The population of the study comprises of the principals and teachers of the schools in Northern India and the parents whose children are studying in those schools. For uniformity, we collected the information from private schools affiliated to Center Board of Secondary Schools (CBSE) in the Northern Indian States.

Research has been defined as a scientific and systematic inquiry either to discover new facts or to verify old facts, their sequences, interrelationships, causal explanation and the adherence to natural laws governing them. It also aims to discover the truth by applying scientific methods through aids the process of knowledge formation and serves as an important source of providing policy suggestions to different businesses, governments, and social organizations. 


\section{Sampling plan and size}

This research aimed to identify the values and their teaching methodologies to be adopted in schools and to identify the factors associated with values education in schools. This was a perceptual study as perceived by school principals, teachers, and parents. The data was collected from three stakeholders; school principals, teachers, and parents at different stages through experts' opinions and focus group interaction and structured questionnaires. The population for this study was the principals, teachers, and parents of the schools affiliated to the Central Board of Secondary Education (CBSE). CBSE schools were selected to have a more homogeneous sample, to let all the parameters being taken in the same set of rules \& regulations and curriculum framework.

Research Technique: Quantitative method using exploratory factor analysis, correlation, regression analysis, Perceptual mapping, values education index.

\subsection{Data Collection and sample size}

Factors related to values education in schools were identified and verified with the help of the literature and focus group discussion. Then data were collected through a structured questionnaire using 5 points Likert scale (1strongly disagree, 2- disagree, 3-neutral, 4-disagree, 5- strongly disagree) from 510 respondents from CBSE affiliated private schools. 32 filled questionnaires were found inappropriate hence rejected straight away. The data from 478 questionnaires were summarized in an excel sheet and above mentioned statistical techniques were applied using SPSS 20 version. The detail of the respondents' background is given in table -4 .

\section{Table 4: Background information of respondents}

\begin{tabular}{|c|c|c|c|c|c|c|c|c|c|c|c|}
\hline $\mathrm{M}$ & $\%$ & $\mathrm{~F}$ & $\%$ & $\mathrm{M}$ & $\%$ & $\mathrm{~F}$ & $\%$ & M & $\%$ & $\mathrm{~F}$ & $\%$ \\
\hline 23 & 16 & 122 & 84 & 78 & 40 & 117 & 60 & 74 & 53 & 64 & 47 \\
\hline 4 & 20 & 48 & 40 & 9 & 12 & 13 & 11 & 12 & 16 & 4 & 06 \\
\hline 19 & 80 & 74 & 60 & 69 & 88 & 104 & 88 & 62 & 84 & 60 & 94 \\
\hline 23 & 100 & 122 & 10 & 78 & 100 & 117 & 100 & 10 & 13 & 25 & 39 \\
\hline \multicolumn{12}{|c|}{ CBSE (Central Board of School Education) } \\
\hline 23 & 10 & 122 & 100 & 78 & 100 & 117 & 100 & -- & -- & -- & -- \\
\hline $\begin{array}{l}\mathrm{De} \\
\text { lhi }\end{array}$ & $\begin{array}{l}\text { U. } \\
\text { P. }\end{array}$ & $\begin{array}{l}\text { Harya } \\
n\end{array}$ & Uttkn & $\begin{array}{l}\text { Del } \\
h\end{array}$ & U.P & Hary & Uttk & $\begin{array}{l}\text { Del } \\
h\end{array}$ & $\begin{array}{l}\text { U. } \\
\text { P }\end{array}$ & Harya & $\begin{array}{l}\text { Uttk } \\
\mathrm{n}\end{array}$ \\
\hline 50 & 45 & 24 & 26 & 49 & 48 & 48 & 50 & 39 & 37 & 35 & 27 \\
\hline
\end{tabular}

(Del - New Delhi, U.P. - Uttar Pradesh, Har - Haryana, Utt - Uttarakhand)

Exploratory factor analysis was carried out by using principal component analysis and the Varimax rotation for extraction of factors, which have immense important values education in schools. Factor analysis output suggested 10 -factor solutions and explains more than $69 \%$ of the variance in the data with Eigen values greater than 1 . The 
result of the factor analysis produces a purified factor composition with comparatively high loadings for the factors. Many variables are loaded high on one factor and this reflected that there is a minimal overlap between the factors and that, all factors are arranged independently. The higher loadings indicated the correlations of the variables with the factors on which they were loaded.

Further for scale purification, experts' opinion was taken to finalize the measurement scale. A series of discussions with supervisors and fellow researchers was conducted. Expert opinion transpired into minor changes in the names of a few dimensions and deletion of some as they were overlapping with other dimensions. Hence the final purified measurement scale was finalized with ten independent factors (family cohesion, Parents engagement, parents conflicts, school administration, Teachers' role, mass media, and internet declining community structure, strong public institutions, society, and religious study) and one dependent variable (perceived effectiveness of values education), as presented in table 5 .

Table: 5 Final values education factors and items after exploratory factor analysis

\begin{tabular}{|c|c|c|c|}
\hline S.No. & Factors & Items & Notation \\
\hline \multirow[t]{3}{*}{1} & Family cohesion (FC) & Grand Parents involvement & FC1 \\
\hline & & Strong family ties & $\mathrm{FC} 2$ \\
\hline & & Empowerment to children & $\mathrm{FC} 3$ \\
\hline \multirow[t]{2}{*}{2} & Parents engagement & Parents education & PE1 \\
\hline & $(\mathrm{PE})$ & Parents involvement in school activity & PE2 \\
\hline \multirow[t]{2}{*}{3} & Parents conflict (PC) & Parents' expectation & PC1 \\
\hline & & Separation of father and mother & $\mathrm{PC} 2$ \\
\hline \multirow[t]{5}{*}{4} & School administration & Separate yoga and meditation class & SA1 \\
\hline & $(\mathrm{SA})$ & Teachers' training and development & SA2 \\
\hline & & $\begin{array}{l}\text { Appropriate curriculum for values } \\
\text { education }\end{array}$ & SA3 \\
\hline & & $\begin{array}{l}\text { Clearly defined an achievable outcome } \\
\text { from values education }\end{array}$ & SA4 \\
\hline & & Democratic system of decision making & SA5 \\
\hline \multirow[t]{4}{*}{5} & Teachers' role (TR) & Quality of teaching & TR1 \\
\hline & & Teacher-students relationship & TR2 \\
\hline & & Teacher as a role model & TR3 \\
\hline & & $\begin{array}{c}\text { Teachers' behavior outside of the } \\
\text { classroom }\end{array}$ & TR4 \\
\hline \multirow[t]{3}{*}{6} & Mass media $\&$ internet & Television and film & MMI1 \\
\hline & (MMI) & Internet media & MMI2 \\
\hline & & $\begin{array}{l}\text { Emergent power of internet media } \\
\text { nurtured youth culture }\end{array}$ & MMI3 \\
\hline \multirow[t]{3}{*}{7} & Community structure & Collapse of community structure & CS1 \\
\hline & $(\mathrm{CS})$ & Crises of established societal norms & $\mathrm{CS} 2$ \\
\hline & & $\begin{array}{l}\text { Students' declining knowledge and } \\
\text { valuing of democratic system }\end{array}$ & $\mathrm{CS} 3$ \\
\hline \multirow[t]{3}{*}{8} & Public institutions (PI) & $\begin{array}{l}\text { Legal framework/ laws for crime and anti } \\
\text { corruption }\end{array}$ & PI1 \\
\hline & & Strong public institutions & PI2 \\
\hline & & $\begin{array}{c}\text { Community participation in public } \\
\text { activities }\end{array}$ & PI3 \\
\hline \multirow[t]{4}{*}{9} & Social orientation (SO) & Achievement orientation in society & SO1 \\
\hline & & Peer group influence & $\mathrm{SO} 2$ \\
\hline & & Responding to undesired behavior & $\mathrm{SO} 3$ \\
\hline & & Trust and trustworthiness & $\mathrm{SO} 4$ \\
\hline \multirow[t]{2}{*}{10} & Religious education & Religious education in school & RE1 \\
\hline & (RE) & Religious tolerance & RE2 \\
\hline
\end{tabular}




\subsection{Design and development of perceptual map}

Multidimensional scaling is a class of procedures for representing the perception and preferences of respondents spatially by means of virtual display. The relationship among factors of values education is represented as a relationship among the points of multidimensional scales. Perceptual mapping is research technique in which collective views of respondents is to be plotted or mapped on a chart or a figure. The map represents the perceived effectiveness of values education in schools.

\subsection{Perceptual Mapping}

Perceptual mapping also known as multidimensional scaling, is very powerful attempt to recreate the mental amp of a human mind as he or she evaluates different objects or factors to make some resemblance of order in his world. It is an attribute free test that looks at the pattern of comparison and tries to decipher the criteria that were used by the person.

Perceptual mapping provides important insights related to the factors impacting values education. It is an exceptional way to find out if there is difference between the perceptions of two groups. It also tracks the swing in perception of respondents about the factors predicting effectiveness of values education.

\subsection{Data Analysis and result}

Perceptual mapping was applied with the help of SPSS 20 on the data collected from respondents. There were ten independent constructs/dimension namely family cohesion (FC), parents engagement (PE), parents conflict (PC), school administration (SA), teachers' role (TR), mass media \& internet (MMI), community structure (CS), public institutions (PI), social orientation (SO) and religious education (RE).the respondent were asked to mark them from 1 to 10 (lowest to highest) according to their contribution toward perceived effectiveness of values education.

It was obvious from the table- 6 below, that highest favorable construct was social orientation and lowest contributing construct was parent's conflict. The religious education was moderate factor but its standard deviation was found very which means there is high variability in the opinion of respondents towards it. The stress value calculated as 0.033 and R square's value was found 0.966 that is an accepted value (more than 0.80 ).

Table 6: Descriptive Statistics value of factors

\begin{tabular}{cccccc}
\hline Constructs & N & Minimum & Maximum & Mean & Std. Deviation \\
\hline FC & 480 & 2 & 6 & 3.70 & .715 \\
PE & 480 & 2 & 7 & 4.86 & 1.399 \\
PC & 480 & 1 & 5 & 2.66 & 1.042 \\
SA & 480 & 2 & 8 & 5.88 & 1.262 \\
TR & 480 & 3 & 8 & 5.14 & 1.082 \\
MMI & 480 & 2 & 7 & 4.37 & .905 \\
CS & 480 & 3 & 8 & 5.55 & 1.198 \\
PI & 480 & 4 & 9 & 6.15 & .910 \\
SO & 480 & 5 & 10 & 7.35 & 2.416 \\
RE & 480 & 9 & 4.62 & \\
\hline
\end{tabular}


In the figure below (figure 2) of perceptual mapping, there are two coordinated or dimensions. It can be easily interpreted from the figure that SO, PI, SA, MMI, FC and PC are close to dimension 1, while CS, TR, PE, RE are close to the dimension 2. Parents conflict (PC) and religious education (RE) may be considered relatively less effective because they are at a longer distance from the central point.

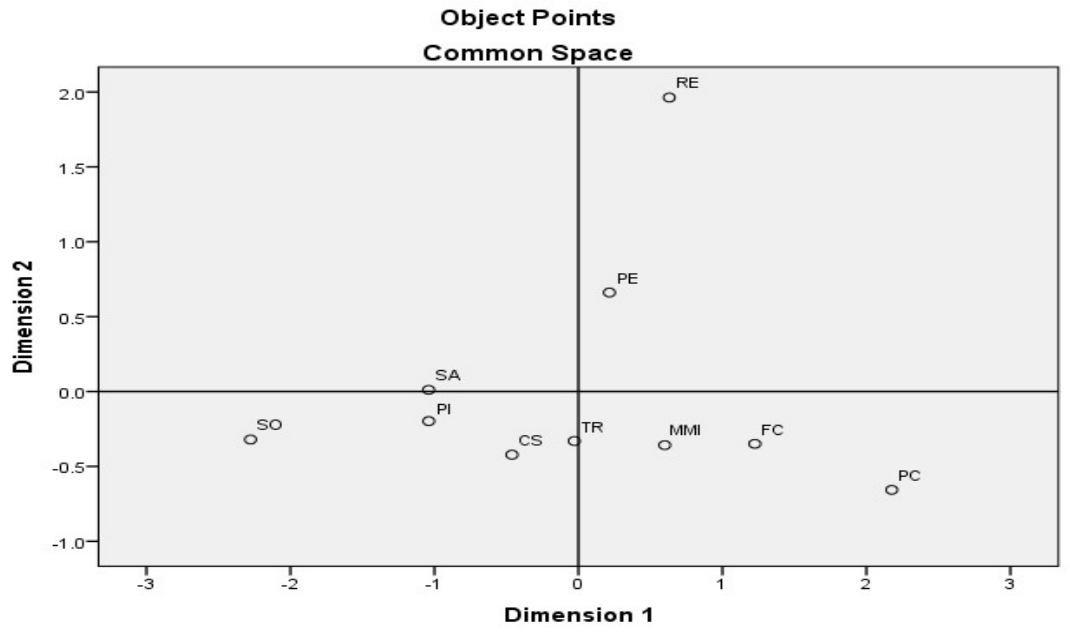

Figure 2: Perceptual mapping of various factors contributing values education

It was also concluded that dimension 1 comprises of society and family; strong factors to weak factors as an impact on values education is concerned i.e. social orientation as the strongest and parent conflict as the weakest factor. It may be labeled as institutional aspects. Dimension 2 comprises of teacher and family and their behavioral (human resource management) aspects and they are teacher's role, parents engagement, religious education, and community structure. It may be associated with the training and development of affiliated people to incre4ase their impact on values education.

The validity of the above statement can be established with the regression model equation in this study which confirms mostly the same findings. In the institutional dimension, society orientation, public institution, school administration have a greater impact on values education so good and supportive policies created by the authorities can improve them, and consequently, values education may improve. In the behavioral and human resource aspect, teachers' role and parents' engagement is found effective. An effective awareness program and special training for teachers and parents could be helpful to improvise the values education program.

\subsection{Correlation Analysis}

Correlation is a statistical tool which summarizes the strength of association between two variables. Correlation is an index which is used to determine whether a linear or straight line relationship exists between two variables. It also indicates the degree to which the variation in one variable is related to the variation in other variables. Since it was proposed by Karl Pearson, it is also known as Pearson's correlation coefficient. The value of correlation coefficient lies between -1 to +1 , which indicates positive or negative and strong or weak degree of correlation between the two variables.

\begin{tabular}{|c|c|c|c|c|c|c|c|c|c|c|c|c|}
\hline \multicolumn{13}{|c|}{ Table 7: Correlations Analysis } \\
\hline \multicolumn{2}{|c|}{ Control Variables } & RES & $\mathrm{FC}$ & $\mathrm{PE}$ & $\mathrm{PC}$ & SA & TR & MMI & $\mathrm{CS}$ & PI & $\mathrm{SO}$ & $\mathrm{RE}$ \\
\hline \multirow{11}{*}{$\begin{array}{l}\text { Perceived } \\
\text { Effectivene } \\
\text { ss of Value } \\
\text { Education } \\
\text { (PEVE) }\end{array}$} & RES & 1.000 & & & & & & & & & & \\
\hline & FC & .030 & 1.00 & & & & & & & & & \\
\hline & $\mathrm{PE}$ & .102 & .200 & 1.00 & & & & & & & & \\
\hline & $\mathrm{PC}$ & .031 & .119 & .120 & 1.00 & & & & & & & \\
\hline & SA & .001 & .126 & .195 & .069 & 1.00 & & & & & & \\
\hline & TR & .047 & .335 & .161 & .092 & .259 & 1.00 & & & & & \\
\hline & MMI & .068 & .094 & .170 & .113 & .088 & .209 & 1.00 & & & & \\
\hline & $\mathrm{CS}$ & .063 & .017 & .042 & .029 & .045 & .015 & .062 & 1.00 & & & \\
\hline & PI & .077 & .237 & .194 & .052 & .144 & .270 & .061 & .005 & 1.00 & & \\
\hline & $\mathrm{SO}$ & .002 & .217 & .284 & .257 & .146 & .121 & .256 & .003 & .332 & 1.00 & \\
\hline & $\mathrm{RE}$ & .123 & .060 & .013 & .009 & .252 & .032 & .025 & .034 & .036 & .153 & 1.00 \\
\hline
\end{tabular}


The majority of variables have a weak positive correlation in which the highest value exist between RES and RE (.123) in the first column, there exist the highest value of correlation in the second column between FC and TR (.335), in the third column between PE and SO (.284), in the fourth column between PC and SO (.257), in the fifth column between SA and TR (,259), in the sixth column between TR and PT (.270), in seventh column between MMI and So (.256), in the eighth column between CS and RE (.034) and in the ninth column it id between SO and RE (.153).

Table: 8 Model Summary

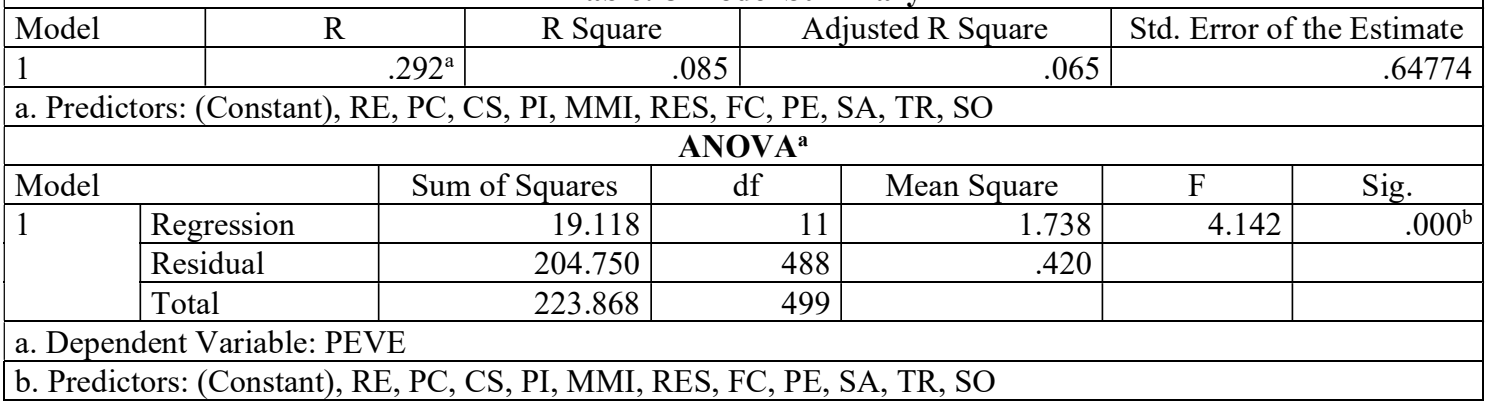

Table 8 is a summary of the model for our identified and authenticated variables (both the dependent and independent) and items of the variables too. This table shows the value of $r, r^{2}$ and adjusted $r^{2}$ for the model that has been obtained. " $r$ " represents the value of the multiple correlation coefficients between the forecasters and the result (Field, 2005). Here, $r$ has a value of 0.292; this value presents the normal correlation between group size and independent variables. " $\mathrm{r}^{2}$ " is a measure of how much of the variability in the results is explained by the forecasters (Field, 2005). The value of $\mathrm{r}^{2}$ is 0.085 which tells us that these ten perceived effectiveness in value education (PEVE). The adjusted " $\mathrm{r}^{2}$ " gives an idea of how well the model generalizes and ideally its value is likely to be the same or very close to, the value of $r^{2}$ (Field, 2005). Here, the difference between $r^{2}$ and adjusted $\mathrm{r}^{2}$ is $0.02 \%(0.085-0.065=0.01)$. This means that if the model were obtained from the population rather than a sample it would account for approximately $0.02 \%$ less variance in the results. Hence we become sure that all our identified variables, chosen tools and techniques, our thought process for the current research study has been scientific and we have followed the right research methodology which is scientific and reliable.

Table 8 also shows the results obtained by an analysis of variance (ANOVA). F-ratio shows the ratio of the enhancement in the calculation of forecasting that results from fitting the model, relative to the incorrectness still exists in the model (Field, 2005). A greater value of F signifies that most of the variation in dependent variable is explained by the regression equation and that the model is valid. A small value of $F$ shows that most of the variation in dependent variable is unexplained (Keller, 2009). From table 4.45 we can see, $\mathrm{F}$ is 4.412 , which is significant at $\mathrm{p}$ (sig.) value $<.001$, i.e. $0.000<0.001$. This result indicates us that there is less than a $0.1 \%$ chance of F-ratio being this large. Therefore, the regression model has significantly improved our ability to predict the perceived effectiveness of value education in the schools of north Indian states.

\subsection{Design and development of value education index}

American Customer Satisfaction Index (ACSI) is a scientific standard of customer satisfaction. Academic research has shown that the ACSI score is a strong predictor of quality, value, and satisfaction. Increasing ACSI scores have been shown to predict loyalty, word-of-mouth recommendations for value education.

The purpose of this study was also to provide information about the value of education indices (VEI) and show the results of VEI study in value education in north Indian states. The VEI model is a structural model based on the assumptions that students' satisfaction is caused by value education index (VEI), here, it has been attempted to develop value education index in secondary education.

Value education index has been introduced in the Indian educational setting, but some index models have been applied at the district and state levels. In this study, the first VEI model has been developed and applied for education in the districts and states as an academic research study to understand the teachers and principals' perceptions and answers from the survey questionnaire. 
On this basis, it is possible to rank all the sampled teachers on the basis of the quality satisfaction index, which will serve as a roadmap for these schools to improve their value education participation. The VEI could be developed for ranking all the sampled institutions

$f(V E I)=1 / N\left[\sum_{\mathrm{i}=1}^{10}\left\{1 / \mathrm{n} \sum_{\mathrm{j}=2}^{5}(\mathrm{Vx})\right\}\right]$

$\mathrm{F}(\mathrm{VEI})=$ Value Education Index

$\mathrm{Vx}=$ Values on designed and developed scale $(1,2,3,4,5)$

$\mathrm{N}=$ Total Number of Components

$\mathrm{n}=(\mathrm{j}=2,3,4,5)$ Number of items within one component $\mathrm{i}(1-10)$

$\mathrm{i}=$ number of component $(1-10)$

$V E I=4.56+4.36+4.26+4.25+4.70+4.09+3.36+3.13+4.08+3.44+3.71=37.58 / 10$

\section{$V E I=3.76$ composite value Education Index}

The value education composite index comes to 3.76 on a five-point scale which is just above to neutral value in the scale viz. from neutral to an agreement. We assume that the respondent's perception of value education is not very satisfactory in schools and other educational institution, so they must be aspiring to go towards agreeing to strongly agree.

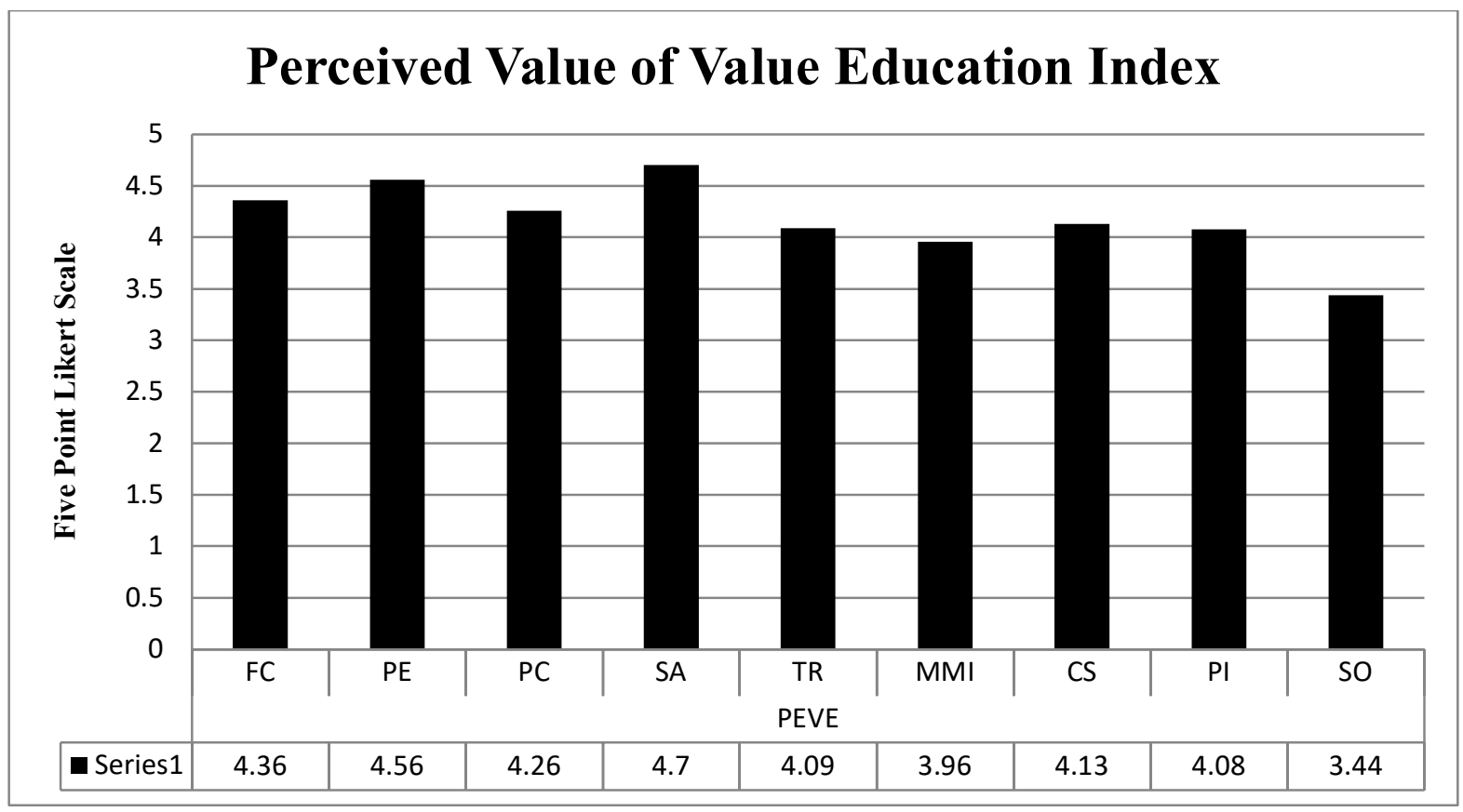

Figure 4: Value Education Index in Indian schools

From the above value education index we infer that social orientation (SO) has the highest score followed by the public the institution (PI), followed by the school administration (SA), then the community structure (CS), then teachers' role (TR), parents engagement (PE), religious education (RE), mass media and internet (MMI), family cohesion (FC), parents conflicts (PC). The construct /factor of social orientation have scored less value on scale therefore schools must instill the social orientation in the students.

\subsection{Findings and conclusion}

From the above figure, we infer that social orientation is the biggest issue in value education in the schools. It is been inferred that our schools lack the socialization of students. The socialization of children shares human values, norms, regulations, and mixing with children of diverse backgrounds. We concluded that deficit of social skill 
creates greater risk for problematic behavior. A major cognitive progress of adolescence is a capability to observe and examine one's own skills and attributes. We would expect social orientation to be impacted by opportunities available, involvement with, and perceived responses for both pro-social and antisocial activities. A positive social orientation is operationalized in the current study as a set of beliefs that include positive self-evaluations of efficiency in problem solving, a sense of self-efficacy in dealing with future disagreements, and determination of pro-social goals in understanding the perceived effectiveness of value education.

The good values have to be inculcated in the individual's mind right from their childhood. In this context, educational institutions play a major role in giving value education to the children from their school-age itself. By understanding the need for the 'Value Education' for the children and students, we focused on Value Education, its need, aims, objectives, its evolution in India, how is it taught globally and also analyzed the role of teachers in promoting the concept.

The School administration is a value-driven region related with the emotions, cultures, and human values that uses technique in structured way. Over the long years, educational administration throughout the world have experienced the influence of logical positivism that is based on rational techniques more than philosophical consideration ignored values and emotions in organizations for the sake of rational problem solving, effectiveness, and strategic planning. However, schools are value-driven organizations that aim to train young students so as to perform social responsibility in society.

A community that values education jealously claims ownership of the process as well as educational institutions. There must be a hub of positive education initiatives. The community was prepared to invest their own time, hardearned money and energy in its development. It became so viable in many respects that the education administration mistakenly classified the school as a private school that was serving the interests of the well off communities. Teachers must have a healthy attitude and should posses' rich values. Teaching is all about attitude positive/ negative towards their job and imparting quality education. Teachers should act as friend, philosopher, mentor, and torchbearer to the student that will shape in value education.

Parent engagement in learning is a key strategy in improving learning outcomes and life opportunities for children and is being recognized. There may be many ways that parents can engage in their child's learning and stay connected with them on their educational journey. Religious education and values education helps in and urges them to think, question, challenge, investigation, and reflect in their search for spiritual meaning, helps students to make informed decisions about matters of personal faith and ethical behavior.

Mass media and the internet are generally used for communication, friendship, socialization, and sharing. However, the use of mass media technologies in education has recently become a current issue. Including social media websites into educational processes is remarkable. Teachers can create a community with simple steps and can establish communication sharing with their students. All these provide convenience for the users. On the other hand, new unethical values appear in a constantly changing world and we have to manage the network between our tangible and intangible values.

Family cohesion or the adolescent's perception of support and care within the family environment differentiates success from failure in school. Family functioning and academic performance also affects the students' personal adjustment and self-concept, family-functioning in terms of communication, problem-solving, responsiveness and involvement was directly related to the child's psychosocial adjustment as measured by the child's attention, and emotional and behavioral regulation.

Family conflicts create unimpressive burden and frustration in minds of the students while they in the learning process. Students lapse their vision and mission. Education without vision is waste, education without value is a crime, and education without mission is a life burden. India has always been known for sound social values and character of its people, the impact of western values has adversely affected the mindset of people which can be rectified only by imbibing our value-oriented educational system, which is of course a big challenge. The challenge has to be met by collective introspections. In brief, the values are the guiding principles of life which are conducive for all-round development to give direction and peace to life. 


\subsection{Limitations and future scope}

The present study was conducted in a north India school environment that too only limited central Board of Secondary Education (CBSE), therefore it cannot be generalized. Moreover, the selected construct was also from a similar school environment; hence there may be differences from researcher to researcher. Future research can conduct pan India level. There is still scope to conduct a study for state education boards, Indian Certificate of Secondary Education (ICSE), junior colleges, technical institutions, etc.

\section{Reference}

Abedini, S. (2011). Sociological analysis of economic and cultural capital role in tendency to social values among the students of Islamic Azad University, Khalkhal Branch. Indian Journal of Science and Technology, 4(9), 1162-1167.

Abu-Tineh, A. M. (2015). The perceived effectiveness of the school based support program. European Journal of Training and Development.

Abu-Tineh, A. M. (2015). The perceived effectiveness of the school based support program. European Journal of Training and Development.

Akhtar, P., Malik, J. A., \& Begeer, S. (2017). The grandparents' influence: Parenting styles and social competence among children of joint families. Journal of child and family studies, 26(2), 603-611.

Al-Serhan, K. A. (2015). The Degree of Adherence to Educational Values by the Students of the University of Jordan - In Their Point of View. International Education Studies, 9(1), 55.

Aspin, D. (2005). A clarification of some key terms in values discussions. Moral education and pluralism (pp. 3257). Routledge.

Bawa, G., \& Bhatnagar, M. (2016). The promotion of nationalism \& internationalism among higher secondary students in district Yamuna Nagar. International Journal of Advanced Education and Research, 1(11), 2328.

Benner, A. D., \& Mistry, R. S. (2007). Congruence of mother and teacher educational expectations and low-income youth's academic competence. Journal of Educational Psychology, 99(1), 140.

Bera, N. (2017). The integration of yoga in modern education: why and how. Int. J. Yoga Physiother. Phys. Educ, 2(3), 37-40.

Berkowitz, M. W. (2011). What works in values education. International journal of educational research, 50(3), 153-158.

Brady, L. (2011). Teacher values and relationship: Factors in values education. Australian Journal of Teacher Education, 36(2), 5.

Bryman, A. (2016). Social research methods. Oxford, UK: Oxford University Press.

Creswell, J. W. (2003). A framework for design. Research design: Qualitative, quantitative, and mixed methods approaches, 9-11.

Davis-Kean, P. E. (2005). The influence of parent education and family income on child achievement: the indirect role of parental expectations and the home environment. Journal of family psychology, 19(2), 294.

Delgado, B. M., \& Ford, L. (1998). Parental perceptions of child development among low-income Mexican American families. Journal of child and family studies, 7(4), 469-481.

Desforges, C., \& Abouchaar, A. (2003). The impact of parental involvement, parental support and family education on pupil achievement and adjustment: A literature review (Vol. 433). London: DfES.

Ferreira-Vorkapic, C., Feitoza, J. M., Marchioro, M., Simões, J., Kozasa, E., \& Telles, S. (2015). Are there benefits from teaching yoga at schools? A systematic review of randomized control trials of yoga-based interventions. Evidence-Based Complementary and Alternative Medicine, 2015.

Furman, G., \& Merz, C. (1996). Schools and community connections: Applying a sociological framework. Coordination among schools, families, and communities: Prospects for educational reform, 323-348.

Gandhi, M., \& Menon, E. F. (1956). My Dear Child. Navajivan Publishing House.

Gaurav, P., Bera, T. K., \& Uddhav, S. S. (2013). Research article yoga for controlling examination anxiety, depression and academic stress among students appearing for indian board examination.

Genc, M. F. (2018). Values education or religious education? An alternative view of religious education in the secular age, the case of Turkey. Education Sciences, 8(4), 220.

Gharote, M. L. (2002). Hathapradipika of Svatmarama: with 10 Chapters. Lonavla: Lonavla Yoga Institute. 
Gibbs, J. P. (1965). Norms: The problem of definition and classification. American Journal of Sociology, 70(5), 586-594.

Gjerde, P. F. (2004). Culture, power, and experience: Toward a person-centered cultural psychology. Human Development, 47(3), 138-157.

Gladkova, A. A. (2013). The role of television in cultivating the values of pluralism and cultural diversity in children. Psychology in Russia: State of the Art, 6(1).

Goode, W. J. (1971). Force and violence in the family. Journal of Marriage and the Family, 624-636.

Gulati, S., \& Pant, D. (2017). Education for values in schools-A framework. New Delhi: National Council of Educational Research and Training, Department of Educational Psychology and Foundations of Education.

Hameed, S. A. (2011). Effect of internet drawbacks on moral and social values of users in education. Aus. J. Basic Applied Sci, 5, 372-380.

Hayes, D. D., \& Varley, B. K. (1965). Impact of social work education on students' values. Social Work, 40-46.

Huitt, W. (2004). Self-concept and self-esteem. Educational psychology interactive, 1, 1-5.

Iscan, C. D., \& Senemoglu, N. (2009). Effectiveness of values education curriculum for fourth grades. Egitim Ve Bilim, 34(153), 1.

Iyer, R. B. (2013). Relation between cooperative learning and student achievement. International Journal of Education and Information Studies, 3(1), 21-25.

Jain, A. (2014). Selling yoga: From counterculture to pop culture. Oxford University Press.

Jain, K. (2012). Declining ethical values in Indian education system. Journal of Education and Practice, 3(12), 23-27.

Jolls, T. (2008). The impact of technology on character education. USA [United States of America]: Center for Media Literacy. Available online also at: http://www. medialit. org/sites/default/files [accessed in Serang City, Indonesia: April 15, 2017].

Katılmış, A. (2017). Values education as perceived by social studies teachers in objective and practice dimensions. Educational Sciences: Theory \& Practice, 17(4).

Lee, M. (1994). Plato's philosophy of education: Its implication for current education (Doctoral dissertation). /

Lepak, D. P., Smith, K. G., \& Taylor, M. S. (2007). Value creation and value capture: A multilevel perspective. Academy of management review, 32(1), 180-194.

Lotz, M. (2014). Parental values and children's vulnerability. Vulnerability: new essays in ethics and feminist philosophy, 242.

Lovat, T., \& Clement, N. (2008). Quality teaching and values education: Coalescing for effective learning. Journal of moral education, 37(1), 1-16.

Lovat, T., \& Schofield, N. (2004). Values education for all schools and systems: A justification and experimental update. New Horizons in Education, 111, 4-13.

Lovat, T., Clement, N., Dally, K., \& Toomey, R. (2010). Values education as holistic development for all sectors: Researching for effective pedagogy. Oxford Review of Education, 36(6), 713-729.

Maitra, P. (2018). Development and Implementation of Module for Value Inculcation through Teaching of Social Science (Doctoral dissertation, Maharaja Sayajirao University of Baroda (India)).

Miller, S. D., \& Sears, D. O. (1986). Stability and change in social tolerance: A test of the persistence hypothesis. American Journal of Political Science, 214-236.

Owens Jr, R. C. (1992). Teacher perceptions concerning their role and the efficacy of moral education in public elementary schools.

Prahalad, C. K., \& Hammond, A. (2002). Serving the world's poor, profitably. Harvard business review, 80(9), 48-59.

Raths, L. E., Harmin, M., \& Simon, S. B. (1966). Values and teaching. Merrill.

Renold, E. (2001). 'Square-girls', femininity and the negotiation of academic success in the primary school. British educational research journal, 27(5), 577-588.

Seshadri, C., Khader, M. A., \& Adhya, G. L. (1992). Education in Values: A Source Book. India National Council of Educational Research and Training.

Shivakumar G., (2013, April 17), India is set to become the youngest country by 2020. The Hindu. Retrieved from https://www.thehindu.com/news/national/india-is-set-to-become-the-youngest-country-by2020/article4624347.ece

Sikula, A. F. (1971). Values and value systems: Importance and relationship to managerial and organizational behavior. The Journal of Psychology, 78(2), 277-286. 
Sikula, A. F. (1971). Values and value systems: Importance and relationship to managerial and organizational behavior. The Journal of Psychology, 78(2), 277-286.

Sills, D. L. (Ed.) (1968). International encyclopedia of social sciences (17 vols.). New York, NY: Macmillan and Free Press.

Simon, S. B., \& Howe, L. W. (1972). 8c Kirschenbaum, H. Values clarification: A handbook of practical strategies for teachers and students. New York: Hart.

Strong-Wilson, T., \& Ellis, J. (2007). Children and place: Reggio Emilia's environment as third teacher. Theory into Practice, 46(1), 40-47.

Suriyachinnavar, K. (2016). Role of parents, guardians and teachers in value education. International Journal of Advance Research and Innovative Ideas in Education (IJARIIE), 1(2), 33-38.

Sylva, K., Melhuish, E., Sammons, P., Siraj-Blatchford, I., \& Taggart, B. (2004). The effective provision of preschool education (EPPE) project technical paper 12: The final report-effective pre-school education.

Thornberg, R. (2007). A classmate in distress: Schoolchildren as bystanders and their reasons for how they act. Social Psychology of Education, 10(1), 5-28.

Thornberg, R. (2008). School children's reasoning about school rules. Research Papers in Education, 23(1), $37-$ 52.

Thornberg, R. (2013). Teachers' views on values education: A qualitative study in Sweden and Turkey. International Journal of Educational Research, 59, 49-56.

Tirri, K. (1998), School as a moral community, Helsinki: Department of Teacher Education, University of Helsinki Titus, D. N. (1994). Values Education in American Secondary Schools.

Tritter, J. (1992). An educated change in moral values: Some effects of religious and state schools on their students. Oxford Review of Education, 18(1), 29-43.

UNESCO (1998). Learning to live together in peace and harmony. UNESCO-APNIEVE Sourcebook for Education and Tertiary Zone Education. Bangkok: UNESCO Principal Regional Office for Asia and the Pacific. Retrieved from https://wfsf.org/resources/leala-pedagogical-resources/reports-by-un-and-otherinternational-organisations/144-unesco-learning-to-live-together-in-peace-and-harmony-1998/file

UNESCO (2014), UNESCO education strategy 2014-2021.Paris: UNESCO. Retrieved from https://unesdoc.unesco.org/ark:/48223/pf0000231288

Venkataiah, N. (Ed.). (1998). Value education. APH Publishing.

Wilson, A. (2010). Knowledge power: Interdisciplinary education for a complex world. Routledge.

Yaşaroğlu, C. (2016). Cooperation and importance of school and family on values education. European journal of multidisciplinary studies, 1(2), 66-71.

Zajda, J. (2018). Globalisation and education reforms: Paradigms and ideologies. In Globalisation and Education Reforms (pp. 1-14). Springer, Dordrecht. 